\title{
Influence of Quality of Work-Life on Organizational Citizenship Behaviour: A Case Study of Selected Ministries in State Secretariat, Abere, Osogbo, Osun State, Nigeria
}

\author{
Solomon Ojo PhD. \\ Department of Human Resource Development \\ Faculty of Management Sciences \\ Osun State University, Nigeria
}

Olonade Zaccheaus O. PhD. (Corresponding author)

Department of Human Resource Development

Faculty of Management Sciences

Osun State University, Nigeria

Bello Luqman

Department of Human Resource Development

Faculty of Management Sciences

Osun State University, Nigeria

Received: April 28, 2020

doi:10.5296/wjbm.v6i1.17288
Accepted: May 25, 2020

Published: May 30, 2020

URL: https://doi.org/10.5296/wjbm.v6i1.17288

\begin{abstract}
The study investigated the influence of quality of work-life on organizational citizenship behaviour (OCB) among civil-servants in selected ministries in State Secretariat, Osogbo, Osun State. A total of 200 civil-servants took part in the study as respondents. Questionnaire was used for data collection in the study. Collected data were analyzed using both Descriptive and Inferential statistics. The findings revealed that quality of work-life have significant influence on organizational citizenship behavior among civil servants, Quality of work-life
\end{abstract}


significantly influenced courtesy among civil servants, Quality of work-life significantly influenced civic virtue among civil servants, Quality of work life significantly influenced conscientiousness among civil servants, Quality of work life significantly influenced sportsmanship among civil servants. Gowever, Quality of work life did not significantly influence altruism among civil. It is therefore concluded that quality of work-life significantly influenced organizational citizenship behavior among civil-servants. It was recommended that ministries should give priority to quality of work-life which willenhance altruism, conscientiousness, civic virtue, sportsmanship and courtesy that will encourage the employees to perform better and show willingness to achieve the organizational goals.

Keywords: Organizational citizenship behavior, Courtesy altruism, Conscientiousness, Civic virtue, Sportsmanship 


\section{Introduction}

Today's companies are constantly searching for ways to stay up with the incessant changes that are typical of the contemporary enterprise environments. The switch of understanding inside the global market has precipitated effectiveness and consequences (Organ \& Konovsky, 1989; MacKenzie, Podsakoff, \& Fetter, 1993; Podsakoff \& MacKenzie, 1994; Walz \& Niehoff, 1996; Podsakoff \& MacKenzie, 1997; Podsakoff, MacKenzie, \& Bommer, 1997; Koys, 2001). the advantages of OCB to the organization used to be highlighted by using Podsakoff, MacKenzie, Paine, and Bachrach (2000) to include: growing co-worker or managerial productivity; releasing sources so that they will be used for greater productive purposes; coordinating activities within and throughout workgroups; reducing the necessity to dedicate scarce sources to simply renovation functions; strengthening the organizations' potential to draw in and hold the easiest employees; increasing the steadiness of the organization's performance; and enabling the organization to adapt more efficiently to environmental changes.

According to Podsakoff (2000), the term organizational citizenship conduct was once first utilized using Bateman and Organ (1983). OCB is one amongst the main extensively studied subjects in organizational behavior lookup (Ehrhart \& Naumann, 2004). As Ertürk (2004) stated, OCB is one of the emerging management principles which will enhance organizational effectiveness, efficiency, and profitability. Additionally, Turnispeed and Rassuli (2005) consider that OCB refers to performing an extra function and behaviors like working in the course of a team with different employees, approaching the place of the job until now and leaving late, helping different employees, the usage of organizational possessions with care, and disseminating positively in a company. As such, OCB can improve co-worker and managerial productivity, supply highest quality effectivity in resource utilization and allocation, decrease managerial expenses, grant higher coordination of organizational things to do throughout individuals, groups, and practical departments, improve organizational effectiveness for high great recruits, extend stability within the organization's performance, and enhance the organizational capability to adapt effectively to environmental adjustments (Ertürk, 2004). There are a variety of antecedents which will have an impact on OCB. These factors encompass job satisfaction, leadership, fairness, perceived organizational support, psychological contract, and dedication (Ravichandran, 2007).

A variety of matters can furnish explanations for organizational citizenship behavior. These include quality of labor life; for the duration of this generation of globalization, keeping the general of human inputs rises from keeping preferred of labor life flawlessly. Rise within the exception of labor life would assist employee's wellness there through the health of the full organization. Quality of labor Life (QWL) has been described as 'The best of the relationship between the people and therefore the complete working environment". Quality of labor-life is anxious with the well-known local weather of work and consequently the influence on work and people yet as on employer effectiveness. The overall performance evaluation of the human assets for the duration of a non-traditional way needs that the employees exhibit voluntary behavior, which is popularly stated within the literature as extra-role behavior and greater particularly as organizational citizenship behavior (Organ \& Konovsky, 1989). 


\subsection{Statement of the Problem}

Little interest has been given to the advantages of organizational citizenship behaviors to the character employees (Bearfield, 2003). As an example, Organ (1988) claimed that organizational citizenship behavior can maximize the effectiveness and productiveness of each of the workers and therefore the organizations, main to the tremendous functioning of the organizations. Similarly, Bergun (2005) referred to that OCB maximizes the efficiency and productiveness of both subordinates and adjustments like progressive and quality practices, technological developments, and technical know-how.

\subsection{Objectives of the Study}

The broad objective of the study was to examine the influence of quality of work life on organizational citizenship behavior with special reference to civil servants in Osun State, Nigeria. The specific objectives of the study are to:

- Determine the influence of quality of work-life on courtesy among civil-servants in Osogbo, Osun State.

- Examine the influence of quality of work-life on civil virtue among civil-servants in Osogbo, Osun State.

- Assess the influence of quality of work-life on altruism among civil-servants in Osogbo, Osun State.

- Determine the influence of quality of work-life on conscientiousness among civil-servants in Osogbo, Osun State.

- Examine the influence of quality of work-life on sportsmanship among civil-servants in Osogbo, Osun State.

- Determine the influence of adequate and fair compensation will significantly influence organizational citizenship behaviour among civil-servants in Osogbo, Osun State.

\subsection{Research Hypotheses}

I. There would be a significant influence of quality of work-life on organizational citizenship behaviour among civil-servants in Osogbo, Osun State.

II. Quality of work-life will significantly influence courtesy among civil-servants in Osogbo, Osun State.

III. Quality of work-life will positively influence civil virtue among civil-servants in Osogbo, Osun State.

IV. Quality of work-life will significantly influence altruism among civil-servants in Osogbo, Osun State

V. Quality of work-life will significantly influence conscientiousness among civil-servants in Osogbo, Osun State. 
IV. Quality of work-life will significantly influence sportsmanship among civil-servants in Osogbo, Osun State.

\section{Theoretical Framework}

\subsection{Kalleberg's Job Satisfaction Theory (Work Values and Job Rewards)}

Kalleberg proposed the "Work Value and Job Rewards" or job pleasure concept in 1977 based totally on six dimensions of work (1977). The six dimensions for identifying the modern reputation of employees' job pleasure consist of intrinsic, convenience, financial, relationships with co-workers, career opportunities, and aid adequacy. Intrinsic refers to a job as a characteristic that allows employees to use their abilities and comprehend their work outcomes. Convenience offers with the workload and ample time to do that. Financial refers to salary, fringe benefits, and job security. Co-worker relationships refer to whether or not colleagues are helpful and friendly. The different dimension of this principle is a career opportunity that is related to employees' want for advancement and recognition. Resource adequacy is the remaining dimension which refers to employees' desire for having to get right of entry to adequate assets to operate well. It also consists of having the necessary equipment and useful and equipped co-workers to perform job tasks correctly (Semerek \& Peterson, 2007).

\subsection{Herzberg Two Factor's Theory (Motivator and Hygiene)}

Herzberg's two-component theory (motivator and hygiene) used to be proposed in 1959 and more often than not focuses on having a sensible strategy in the direction of motivating personnel (Herzberg, 1959). This preliminary thinking indicated that the elements causing job pride had been contrary to the factors inflicting job dissatisfaction. Thus, Herzberg performed a survey study to distinguish the elements that made employees' feeling high quality and which made them experience negative. The findings of Herzberg's study on 200 technicians and accountants from over nine groups in the US had been posted in 1959 (Tan \& Waheed, 2011). In Herzberg's learn about most of these specialists have been requested to explain experiences that made them feel either extraordinarily bad or fairly exact about their jobs and rate their feelings on these occasions. Responses about correct feelings are usually related to job content material (motivators), whereas responses about bad feelings are associated with job context (hygiene factor). Motivator includes factors built into the job itself, such as achievement, recognition, responsibility, development, and readability of mission.

\subsection{Structural Functionalism Theory of Work-Life}

This principle can be traced returned to the early 20th century, the era where the industrial revolution main way to separate economic work from personal existence (Clark, 2000). The 19th century's technological advancements in equipment and manufacturing contributed at the early stages to this separation of work from the household (Clark, 2000). This concept implies that life is concerned often with two separate spheres: a productive existence which happens in the place of job and positive lifestyles which is domestic (Oslen, 1983). Structural functionalism idea believes in the existence of radical separation between work (institution, workplace, or market) and families. According to this theory, these two (workplace and family) work high-quality "when guys and women specialize their things to do in separate spheres, 
girls at domestic doing expressive work and guys in the administrative center performing instrumental tasks" (Kingsbury \& Scanzoni, 1993; as stated in MacDermid, 2005).

\subsection{Border Theory of Work-Life}

Clark (2000) presented a work/life border concept a new dimensional theory about work-life balance. Clark opines that each person's role takes area within a unique area of life, and these domains are separated by way of borders that may additionally be bodily, temporal, or emotional. The concept addresses the trouble of "crossing borders "between domains of life, particularly the domains of home and work. According to this theory, the flexibility and restriction to change over the boundaries between people's work and family lives will have an effect on the degree of integration and determines the ease of transitions between the two spheres, and the stage of warfare between these domains are closely related. Boundaries that are bendy facilitate integration between work and domestic domains. When domains are enormously integrated, the mutual transition is easier, however, that may lead to work-family conflict. Conversely, when these domains are segmented, the transition is more effortful, but the work-family battle is less likely (Bellavia \& Frone, 2005).

\subsection{Theory of Planned Behaviour}

The idea of deliberate behavior (TPB) is one of the most broadly referred to and applied behavior theories. It is one of an intently inter-related family of theories that undertake a cognitive strategy to explaining behaviour that centers on individuals' attitudes and beliefs. The TPB (Ajzen 1985; Ajzen \& Madden 1986) evolved from the theory of reasoned motion (Fishbein \& Ajzen 1975) which posited intention to act as the exceptional predictor of behaviour. The intention is itself a result of the mixture of attitudes closer to a behaviour. That is the tremendous or terrible assessment of the behaviour and its anticipated outcomes, and subjective norms, which are the social pressures exerted on a character resulting from their perceptions of what others think they have to do and their inclination to comply with these. The TPB brought the third set of elements as affecting intention (and behaviour); perceived behavioural control. This is the perceived ease or situation with which the individual will be in a position to function or elevate out the behaviour, and is very comparable to notions of self-efficacy (Bandura 1986).

\subsection{The Health Belief Model}

The health belief model (HBM) (Hochbaum, 1958; Rosenstock 1966; Becker, 1974; Sharma \& Romas, 2012) is a cognitive model which posits that behaviour is determined by using several beliefs about threats to an individual's well-being and the effectiveness and consequences of precise moves or behaviours. Some constructions of the mannequin characteristic the notion of self-efficacy (Bandura 1997) alongside these beliefs about actions. These beliefs are further supplemented by extra stimuli referred to as' cues to action' which trigger authentic adoption of behaviour. The perceived chance is at the core of the HBM as it is linked to a person's 'readiness' to take action. It consists of two sets of beliefs about an individual's perceived susceptibility or vulnerability to a unique danger and the seriousness of the expected penalties that can also result from it. The perceived advantages associated with a behaviour, that is its 
probable effectiveness in reducing the threat, are weighed in opposition to the perceived charges of and bad penalties that may also result from it (perceived barriers), such as the facet consequences of treatment, to establish the average extent to which a behaviour is beneficial. The individual's perceived capability to undertake the behaviour (their self-efficacy) is beside the key element of the model. Finally, the HBM identifies two sorts of 'cue to action'; internal, which in the health context includes symptoms of sick health, and external, which consists of media campaigns or the receipt of other information.

\subsection{Social Practice Theory}

Social practice theory (SPT) is more and more being utilized to the analysis of human behavior, especially in the context of strength use and consumption. Rather than a single principle or 'model', Social exercise theory is something of an umbrella method below which several factors of the principle are pursued. The central insight of Social exercise idea is the focus that human 'practices' (ways of doing, 'routinized behaviour', habits) are themselves preparations of quite a number interconnected elements, such as bodily and intellectual activities, norms, meanings, technological know-how use, knowledge, which form peoples actions or 'behaviour' as section of their everyday lives (Reckwitz, 2002). The approach specifically emphasizes the material contexts (also 'socio-technical infrastructures') inside which practices occur, drawing attention to their have an impact on upon behaviour (the production and copy of practices). The idea that non-human 'actors' have a position to play in inflicting certain consequences or 'behaviour' attracts on the actor-network principle of Bruno Latour. Shove (2010) notes: 'Put simply, roads, railways, freezers, heating systems, etc. are not innocent points of the history (Shove, 2010).

\subsection{Empirical Review}

Igudia and Ohue (2008) examined "Organisational Citizenship Behavior and therefore the Performance of Government-Owned Medical Centres in Nigeria: The case of Edo State". They concluded that over the years, there are hues and cries by people who seek treatment and a focus from government-owned health-care centres in Nigeria. The health-care givers in these institutions, particularly in Edo State, are accused of failure to exhibit certain internationally acceptable discretional behaviours towards their patients/clients outside their core job descriptions and responsibility. The failure of those health givers to demonstrate such discretional behaviour has been reported to negatively impact the performance level of such organisations in reference to their core duties and responsibilities to the final public. to determine the veracity of such claims and take part the controversy to work out the likelihood that such discretionary behaviour could impact the amount of organisational performance, this study examines the character of relationship that exists between organisational citizenship behaviour and therefore the performance of government-owned medical centres in Edo State of Nigeria. The study used a survey research design. 356 respondents were surveyed. Krejcie and Morgan (1970) sampling technique was used for the study. Using the Pearson product moment coefficient of correlation analysis, the study finds that there exist a powerful positive relationship between conscientiousness to duty (as a measure for discretionary behaviour) and competitive advantage (as a proxy for performance) of 
government-owned medical centres. The study recommends, that the staff of the government-owned medical institutions should inter alia: work for extra hours when necessary, learn to present their colleagues an aid when needed, and be punctual to figure because of these could positively impact the performance level of their organisations in health healthcare delivery.

Osaro and Jeremiah (2004) administered research on the determinants of citizenship behavior in Nigerian organizations. From their study, for any organisation to succeed, its people must be able and willing to deliver optimally on their verbal description. However, beyond meeting the need of job descriptions is that the greater need for workers to exhibit organisational citizenship behaviour (OCB).

Pradihan, Jena, and Kumar (2017) investigated the effect of work-life balance on organisational commitment. They observed that balancing work and life stands as an on-going challenge in contemporary times. Today's global market place demands conflicting professional responsibilities within the style of unflinching 'work-life commitment'. In organizational context, a top quality of work-life balance is important to continue attracting and retaining its employees. This sort of practice has significant implications on employee attitudes, behaviours, and well-being yet as organizational effectiveness. In contemporary times, many multinational corporations (MNCs) are found specializing in organizing work-life programmes as these have become an intelligent option to help in increasing job satisfaction among employees and in career accomplishment. On the opposite hand, the popular concept of 'organizational citizenship behaviour' inherently strives from its employees to increase their discretionary behaviours beyond the expected normal duties. However, this sort of anticipated behaviour of employees is somehow silently contradicting the notion of work-life balance. Thus, during this context, the influences of work-life balance on organizational citizenship behaviour have to be explored. Keeping this objective in mind, this study examines the effect of work-life balance on organizational citizenship behaviour. It examines the role of organizational commitment on the connection between work-life balance and organizational citizenship behaviour. A survey was conducted employing a set of established questionnaire on work-life balance, organizational citizenship behaviour and organizational commitment with employees and executives of producing industries in eastern India.

\section{Methodology}

The research design adopted for this study was survey research which employed the Ex-post Facto design. The independent variable was Quality of Work Life while the dependent variable was Organizational Citizenship Behavior. Organizational Citizenship Behavior (OCB) had some dimensions, viz Courtesy, Civic Virtue, Altruism, Conscientiousness and Sportsmanship.

The target population of the study consisted of all employees working in the selected Ministries of Agriculture, Education, and Finance in Osun State of Nigeria. As at the time the study was conducted, the civil servants in those Ministries were; Ministry of Agriculture 570, Education - 1035 and Finance - 491 summing up 2096 in total. The sample size was 
calculated using Taro Yamane's formula (Yamane, 1973) with 95\% confidence level. A sample size of 212 was arrived at.

\subsection{Research Instrument}

The research instrument used in carrying out this study was a structured questionnaire. This is to measure the Influence of Quality of Work-Life on Organisational Citizenship Behavior among Civil-Servants in Osogbo, Osun State. The questionnaire consists of three (3) different sections namely section A, B, and C. Section A contained the socio-demographic information about the respondents such as age, sex, marital status, education qualification, religion and years of experience. Section B consisted of Quality of Work-life Scale developed by Vijayalakshmi (2005). It contains (20) questions measured on a 5-point Likert Scale, namely Strongly Agree (SA), Agree (A), Undecided (U), Disagree (D) and Strongly Disagree (SD). The Cronbach's alpha coefficients for reliability of the scale were .88. Section C consist of Organizational Citizenship Behaviour Scale which was developed by Podsakoffs (1990). It measures altruism, courtesy, civil virtue, sportsmanship and conscientiousness. This scale contained 15 items (3 for each dimension) measured on a 5 point Likert Scale, namely Strongly Agree (SA), Agree (A), Undecided (U), Disagree (D) and Strongly Disagree (SD). The value of Cronbach's Alpha for the item set is 0.702 .

Two hundred and twelve copies of the questionnaire were administered by the authors in the selected Ministries with two hundred filled copies retrieved. The data gathered from socio-demographic information were presented in form of frequency tables with percentages while the stated hypotheses were tested with inferential statistics. Specifically using T-testforindependent measures. The Statistical Package for Social Sciences (SPSS) Version 21.0 was used for computation.

\section{Results}

From the Socio-demographic characteristics, the study revealed that $87(43.5 \%)$ of the respondents were male while $113(56.5 \%)$ were female. Also, the finding in terms of age group of the study revealed that $23(11.5 \%)$ of the respondents were less than 20 years; $38(19 \%)$ of the respondents were within age bracket $25-29$ years; $43(21.5 \%)$ of the respondents were within age bracket 30-34 years; $41(20.5 \%)$ of the respondents were within age bracket $35-39$ years; 37 (18.5\%) were within age bracket above 40-44 years while 18(9\%) were within age bracket 45years and above. Based on educational qualifications of the respondents, the study showed that $45(22.5 \%)$ of the respondents were holders of OND; 68(34\%) were holders of First Degree/Higher National Diploma; 40(20\%) of the respondents were holders of Postgraduate Diploma; 32(16\%) of the respondents were holders of Masters Degree; $3(1.5 \%)$ of the respondents were holders of Ph.D. while 12(6\%) of the respondents were holders of other educational qualifications. Also, in terms of length of working experience, the study showed that $27(10.5 \%)$ of the respondents had worked between 0-4 years; $39(19.5 \%)$ of the respondents had worked between 5-9years; 52(26\%) of the respondents had worked between 10-14 years; 68(34\%) of the respondents had worked between 15-19 years; while 20(10\%) had worked between 20 years and above. 


\subsection{Test of Hypothesis One}

This stated that there would be a significant influence of quality of work life on organizational citizenship behavior among civil servants in Osogbo, Osun State.. The hypothesis was tested by T- test for independent measures. The result is shown in table 1 below.

Table 1. A summary table of t-test for independent measures showing the influence of quality of work life on organizational citizenship behaviour among civil servants in Osogbo, Osun State

\begin{tabular}{|l|l|l|l|l|r|r|}
\hline Quality of Work Life & \multicolumn{1}{|c|}{$\mathrm{N}$} & $\overline{\mathrm{X}}$ & \multicolumn{1}{|c|}{ SD } & Df & t & P \\
\hline HIGH & 92 & 47.15 & 16.45 & & & \\
\cline { 1 - 4 } & 108 & 38.32 & 38.32 & 198 & 10.33 & $<.01$ \\
\hline
\end{tabular}

Source: Author's Fieldwork, 2019.

The result in table 1 above revealed that there was a significant influence of quality of work life on organizational citizenship behavior among civil servants in Osogbo, Osun State [ $\mathbf{t}$ $(\mathbf{1 9 8})=\mathbf{1 0 . 3 3}, \mathrm{P}<.01]$

Therefore, the hypothesis two was supported by the result of the study.

\subsection{Hypothesis Two}

This stated that quality of work life would significantly influence courtesy among civil servants in Osogbo, Osun State. The hypothesis was tested by T- test for independent measures. The result is shown in table 2 below:

Table 2. A summary table of t-test for independent measures showing the influence of quality of work life on courtesy among civil servants in Osogbo, Osun State

\begin{tabular}{|l|l|l|l|l|l|c|}
\hline Quality of Work Life & \multicolumn{1}{|c|}{$\mathrm{N}$} & \multicolumn{1}{|c|}{$\overline{\mathrm{X}}$} & \multicolumn{1}{|c|}{ SD } & Df & t & P \\
\hline HIGH & 92 & 8.31 & 3.66 & & & \\
\cline { 1 - 4 } LOW & 108 & 5.75 & 2.82 & 198 & 4.84 & $<.01$ \\
\hline
\end{tabular}

Source: Author's Fieldwork, 2019.

The result in table 2 above revealed that quality of work life significantly influenced courtesy (a dimension under organizational citizenship behavior) among civil servants in Osogbo, Osun State $[\mathbf{t}(\mathbf{1 9 8})=\mathbf{4 . 8 4}, \mathbf{P}<.01]$. Therefore, the hypothesis two was supported by the result of the study. 


\subsection{Hypothesis Three}

This stated that quality of work life would significantly influence civic virtue among civil servants in Osogbo, Osun State. The hypothesis was tested by T- test for independent measures. The result is shown in table 3 below.

Table 3. A summary table of t-test for independent measures showing the influence of quality of work life on civic virtue among civil servants in Osogbo, Osun State

\begin{tabular}{|l|l|l|l|l|r|r|}
\hline Quality of Work Life & \multicolumn{1}{|c|}{$\mathrm{N}$} & $\overline{\mathrm{X}}$ & $\mathrm{SD}$ & $\mathrm{Df}$ & $\mathrm{t}$ & $\mathrm{P}$ \\
\hline HIGH & 92 & 9.02 & 3.95 & & & \\
\cline { 1 - 4 } LOW & 108 & 6.54 & 3.03 & 198 & 8.76 & $<.01$ \\
\hline
\end{tabular}

Source: Author's Fieldwork, 2019.

The result in table 3 above revealed that quality of work life significantly influenced civic virtue (a dimension under organizational citizenship behavior) among civil servants in Osogbo, Osun State $[\mathbf{t}(\mathbf{1 9 8})=\mathbf{8 . 7 6}, \mathbf{P}<.01]$ Therefore, the hypothesis three was supported by the result of the study.

\subsection{Hypothesis Four}

This stated that quality of work life would significantly influence altruism among civil servants in Osogbo, Osun State. The hypothesis was tested by T- test for independent measures. The result is shown in table 4 below.

Table 4. A summary table of t-test for independent measures showing the influence of quality of work life on altruism among civil servants in Osogbo, Osun State

\begin{tabular}{|l|l|l|l|l|l|c|}
\hline Quality of Work Life & \multicolumn{1}{|c|}{$\mathrm{N}$} & $\overline{\mathrm{X}}$ & $\mathrm{SD}$ & $\mathrm{Df}$ & $\mathrm{t}$ & $\mathrm{P}$ \\
\hline HIGH & 92 & 6.29 & 3.81 & & & \\
\cline { 1 - 4 } LOW & 108 & 7.91 & 4.27 & 198 & 1.02 & $>05$ \\
\hline
\end{tabular}

Source: Author's Fieldwork, 2019.

The result in table 4 above revealed that quality of work life did not significantly influence altruism (a dimension under organizational citizenship behavior) among civil servants in Osogbo, Osun State $[\mathbf{t}(\mathbf{1 9 8})=\mathbf{1 . 0 2}, \mathbf{P}>\mathbf{. 0 5}]$. Therefore, the hypothesis four was not supported by the result of the study.

\subsection{Hypothesis Five}

This stated that quality of work life would significantly influence conscientiousness among civil servants in Osogbo, Osun State. The hypothesis was tested by T- test for independent measures. The result is shown in table 5 below. 


\section{$\triangle$ Macrothink}

World Journal of Business and Management

ISSN 2377-4622

2020, Vol. 6, No. 1

Table 5. A summary table of t-test for independent measures showing the influence of quality of work life conscientiousness among civil servants in Osogbo, Osun State

\begin{tabular}{|l|l|l|l|l|l|l|}
\hline Quality of Work Life & \multicolumn{1}{|c|}{$\mathrm{N}$} & \multicolumn{1}{|c|}{$\overline{\mathrm{X}}$} & \multicolumn{1}{|c|}{ SD } & Df & t & P \\
\hline HIGH & 92 & 8.67 & 3.05 & & & \\
\cline { 1 - 4 } & 108 & 6.41 & 2.73 & 198 & 4.73 & $<.01$ \\
\hline
\end{tabular}

Source: Author's Fieldwork, 2019.

The result in table 5 above revealed that quality of work life significantly influenced conscientiousness a dimension of organizational citizenship behavior) among civil servants in Osogbo, Osun State $[\mathbf{t}(\mathbf{1 9 8})=\mathbf{4 . 7 3}, \mathbf{P}<. \mathbf{0 1}]$. Therefore, the hypothesis five was supported by the result of the study.

\subsection{Hypotheses Six}

This stated that quality of work life would significantly influence sportsmanship among civil servants in Osogbo, Osun State. The hypothesis was tested by T- test for independent measures. The result is shown in table 6 below.

Table 6. A summary table of t-test for independent measures showing the influence of quality of work life on sportsmanship among civil servants in Osogbo, Osun State

\begin{tabular}{|l|l|l|l|l|l|l|}
\hline Quality of Work Life & \multicolumn{1}{|c|}{$\mathrm{N}$} & \multicolumn{1}{|c|}{$\overline{\mathrm{X}}$} & \multicolumn{1}{|c|}{ SD } & Df & $\mathrm{t}$ & $\mathrm{P}$ \\
\hline HIGH & 92 & 10.57 & 3,82 & & & \\
\cline { 1 - 5 } & 118 & 7.63 & 7.63 & 198 & 6.45 & $<.01$ \\
\hline
\end{tabular}

Source: Author's Fieldwork, 2019.

The result in table 6 above revealed that quality of work life significantly influenced sportsmanship ( a dimension under organizational citizenship behavior) among civil servants in Osogbo, Osun State $[\mathbf{t}(\mathbf{1 9 8})=\mathbf{6 . 4 5}, \mathbf{P}<\mathbf{. 0 1}]$. Therefore, the hypothesis six was supported by the result of the study.

\section{Discussion}

The main objective of the study was to investigate the influence of quality of work-life on organizational citizenship behaviour. The study establishes the framework that is found to be interlinked with many literatures in the past. However, this study attempts to provide a practical scenario in selected Ministries in Abere, State Secretariat, Osogbo, Osun State, this will help the corporate sectors and future researchers and scholars in various aspects and helping them to try an intensive study in Nigeria context. It can be suggested that the demographic variables such as gender, age, tenure should be consider while explaining the OCB (Farooqui, 2012).

The hypothesis one which stated that there will be a significant influence on quality of 
work-life on organizational citizenship behaviour among civil-servants in Osogbo, Osun State was supported by the study. The findings indicated that quality of work-life significantly influenced courtesy among civil-servants in Osogbo, Osun State. This indicated that civil-servants who experienced higher level of quality of work-life reported more organizational citizenship behaviour than civil-servants who experienced lower level of quality of work-life.

The hypothesis two which stated that quality of work-life significantly influenced courtesy among civil servants in Osogbo, Osun State. This indicated that civil- servants who experienced good and quality of work-life tends to relate calmly and friendly with other co-workers and this promote OCB. In support of this Law (2005) stated that courtesy is a discretionary behavior that aims at preventing work related conflicts with other personnel., thus this regulates problems arising from word's literal definition of being polite and considerate others which influence organizational citizenship behavior.

The hypothesis three which stated thatquality of work-life significantly influenced civil virtue among civil servants in Osogbo, Osun State. This connote that civil-servants who experienced high level of quality of work-life do have deep concerns and active interest in the life of the organization and this influence OCB.In keeping pace with the developments in the organization, following closely the changes in the organization and active involvement in other's adopting changes (Ozenİşbaşı, 2000). Civic virtue: Includes behaviors showing a strong sense of responsibility toward the organization, for example, offering advice and suggestions or trying to solve problems thus improving efficiency (Ozturk, 2010).

The hypothesis four which statedthat quality of work-life did not significantly influence altruism among civil servants in Osogbo, Osun State. This indicated that most of the civil-servants doesn't exhibit the essential helping behavior which can be directed within or outside of the organization and this affects OCB in a negative way. Organ (1988) opined that at the heart of this behavior lies coworkers' sense of helping each other. Altruistic behaviors help develop voluntary collaboration among work groups in the organization.

The hypothesis five which stated that quality of work-life significantly influenced conscientiousness among civil servants in Osogbo, Osun State. This indicated that once an employee quality of work-life is enhanced, such employees adhere to organizational rules/ norms and it depicts the reliability and dependability of the employee within the organization. Konovsky and Organ (1996) found in their study that, conscientiousness was significantly inter-related to all types (facets) of OCB. According to Yen and Neihoff (2004), more conscientious employees will stay informed with up-to-date knowledge about products or services offered.

The hypothesis six which stated that quality of work-life significantly influenced sportsmanship among civil servants in Osogbo, Osun State. This indicated that as higher the quality of work-life experienced by workers the higher the willingness on the part of the employee that signifies the employee's tolerance of less-than-ideal organizational circumstances without complaining and blowing problems out of proportion. George and Betten (1990) noted that sportsmanship is expected to be positively related to work group 
performance. The more willing employees are to be "good sports" and go along with necessary changes in their work environment, the less time and energy a manager wastes in getting their cooperation.

\section{Conclusion}

Based on the obtained findings, it is therefore concluded that:

- There was a significant influence of quality of work-life on organizational citizenship behaviour among civil servants in Osogbo, Osun State.

- Quality of work-life significantly influenced courtesy among civil servants in Osogbo, Osun State.

- Quality of work-life significantly influenced civil virtue among civil servants in Osogbo, Osun State.

- Quality of work-life did not significantly influence altruism among civil servants in Osogbo, Osun State.

- Quality of work-life significantly influenced conscientiousness among civil servants in Osogbo, Osun State.

- Quality of work-life significantly influenced sportsmanship among civil servants in Osogbo, Osun State.

\section{Recommendations}

Based on the findings of the study, the following are move;

1) Ministries should give more priority to all the variables such as altruism, conscientiousness, civic virtue, sportsmanship and courtesy that will encourage the employees to perform better and show willingness to achieve the organizational goals.

2) The ministries should also take care in managing the civil-servants and gain their willingness to work towards the organizational goal.

\section{References}

Ajzen, I. (1991). The theory of planned behavior. Organizational Behavior and Human Decision Processes, 50(2), 179-211.

Ajzen, I., \& Madden, T. J. (1986). Prediction of goal-directed behavior: Attitudes, intentions, and perceived behavioral control. Journal of Experimental Social Psychology, 22(5), 453-474.

Bateman, T. S., \& Organ, D. W. (1983). Job satisfaction and the good soldier: The relationship between affect and employee "citizenship." Academy of Management Journal, 26(4), 587-595.

Bearfield, S. (2003). Quality of working life: comparing the perceptions of professionals and clerical sales and service workers. Retrieved September 19, 2019 from http://www.accirt.com

Becker, M. H. (1974). The health belief model and personal health behavior. Health Education 
Monographs, 2, 324-508

Bellavia, G., \& Frone, M. (2005). Work-family conflict. In J. Barling, E. K. Kelloway, \& M. Frone (Eds.), Handbook of work stress Thousand Oaks (pp. 185-221). California: Sage Publications.

Bergun, N. (2005). The relationship between social power and organizational citizenship behavior: The mediation role of procedural justice, organisational commitment and job satisfaction in a context of private commercial bank in Bangladesh. Journal of Psychology, 72(9), 456-584.

Clark, S. (2000). Work-Family Border Theory: A New Theory of Work-Life Balance. Human Relations, 53, 747-770.

Ehrhart, M. G., \& Naumann, S. E. (2004). Organizational Citizenship Behavior in Work Groups: A Group Norms Approach. Journal of Applied Psychology, 89(6), 960-974.

Ertu"rk, Y. (2004). Convergence and divergence in the status of Muslim women: The cases of Turkey and Saudi Arabia. International Sociology, 6(3), 307-320

Farooqui, M. R. (2012). Measuring Organizational Citizenship Behavior (OCB) as a Consequence of Organizational Climate (OC). Asian Journal of Business Management, 4(3), 294-302.

George, J. M., \& Bettenhausen, K. (1990). Understanding prosocial behavior, sales performance, and turnover: A group level analysis in service context. Journal of Applied Psychology, 75, 698-70.

Hochbaum, G. M. (1958). Public participation in medical screening programmes: A socio-psychological study. Washington DC: Government Printing Office.

Kingsbury, N., \& Scanzoni, J. (1993). Structural-functionalism. In W. Doherty, R. LaRossa, W. Schumm, \& S. Steinmetz (Eds.), Sourcebook of theories and methods about families (pp. 195-217). New York: Plenum.

Konovsky, M. A., \& Organ, D. W. (1996). Dispositional and contextual determinants of organizational citizenship behavior. Journal of Organizational Behavior, 17(3), 253-266.

Koys, D. J. (2001). The effects of employee satisfaction, Organizational citizenship behavior and turnover on organizational effectiveness: A unit-level, longitudinal Study. Personnel Psychology, 54(7), 101-114.

Krejcie, R. V., \& Morgan, D. W. (1970). Determining sample size for research activities. Educational and Psychological Measurement, 30(3), 607-610.

MacDermid, S. M. (2005). (Re)Considering Conflict between Work and Family. In E. E. Kossek \& S. J. Lambert (Eds.), LEA's organization and management series. Work and life integration: Organizational, cultural, and individual perspectives (pp. 19-40). Lawrence Erlbaum Associates Publishers. 
MacKenzie, S. B., Podsakoff, P. M., \& Fetter, R. (1993). The impact of organizational citizenship behavior on evaluations of salesperson performance. Journal of Marketing, 57(1), 70-80. https://doi.org/10.2307/1252058

Olson, D. H., Russell, C. S., \& Sprenkle, D. H. (1983). Circumplex Model of marital and family systems: VI. Theoretical update. Family Process, 22(1), 69-83. https://doi.org/10.1111/j.1545-5300.1983.00069.x

Organ, D. W. (1988). Issues in organization and management series. Organizational citizenship behavior: The good soldier syndrome. Lexington Books/D. C. Heath and Com.Osaro and Jeremiah (2004).

Organ, D. W., \& Konovsky, M. (1989). Cognitive versus affective determinants of organizational citizenship behavior. Journal of Applied Psychology, 74(1), 157-164. https://doi.org/10.1037/0021-9010.74.1.157

Özen İşbaşı, J. (2001). Çalışanların yöneticilere duydukları güvenin ve örgütsel adalete ilişkin algılarının vatandaşlık davranışının oluşumuna etkisi. Yönetim Araştırmaları Dergisi, 1, 51-73.

Ozturk, I, (2010). A literature survey on energy-growth nexus. Energy Policy, 38(1), 340-349,

Podsakoff, P. M., \& MacKenzie, S. B. (1994). An examination of the psychometric properties and nomological validity of some revised and reduced substitutes for leadership scales. Journal of Applied Psychology, 79(5), 702-713.

Podsakoff, P. M., Ahearne, M., \& MacKenzie, S. B. (1997). Organizational citizenship behavior and the quantity and quality of work group performance. Journal of Applied Psychology, 82(2), 262-270. https://doi.org/10.1037/0021-9010.82.2.262

Podsakoff, P. M., MacKenzie, S. B., Paine, J. B., \& Bachrach, D. G. (2000). Organizational citizenship behaviors: A critical review of the theoretical and empirical literature and suggestions for future research. Journal of Management, 26(3), 513-563. https://doi.org/10.1177/014920630002600307

Pradihan, Jena, \& Kumar. (2017).

Ravichandran, R. (2007). Perceived Sources of Stress among the Teachers. Journal of the Indian Academy of Applied Psychology, 33, 133-136.

Rosenstock, M. (1966). Why people use health services. The Milbank Memorial Fund Quarterly, 44, 94-127.

Sharma, M., \& Romas, J. A. (2012). Theoretical foundations of health education and health promotion. Sudbury, MA: Jones \& Bartlett Learning.

Shove, E. (2010). Beyond the ABC: Climate change policy and theories of social change. Environment and Planning A: Economy and Space, 42(6), 1273-1285. https://doi.org/10.1068/a42282

Smerek, R., \& Peterson, M. (2007). Examining Herzberg's theory: Improving job satisfaction 


\section{Macrothink}

World Journal of Business and Management

ISSN 2377-4622

2020, Vol. 6, No. 1

among non-Academic employees at a University. Research in Higher Education, 48(2), 229-249.

Tan, T. H., \& Waheed, A. (2011). Herzberg's motivation-hygiene theory and job satisfaction in the Malaysian retail sector: Mediating effect of love of money. Asian Academy of Management Journal, 16(8), 73-94.

Turnipseed, D. L., \& Rassuli, A. (2005). Performance Perceptions of Organizational Citizenship Behaviours at Work: A Bi-Level Study among Managers and Employees. British Journal of Management, 16(3), 231-244. https://doi.org/10.1111/j.1467-8551.2005.00456.x

Vijayalakshmi, A. (2005). Teacher Effectiveness and Job Satisfaction of Women Teachers. Edutracks, 4(7), 7-9.

Walz, S. M., \& Niehoff, B. P. (2000). Organizational Citizenship Behaviors: Their Relationship to Organizational Effectiveness. Journal of Hospitality \& Tourism Research, 24(3), 301-319. https://doi.org/10.1177/109634800002400301

\section{Copyright Disclaimer}

Copyright for this article is retained by the author(s), with first publication rights granted to the journal.

This is an open-access article distributed under the terms and conditions of the Creative Commons Attribution license (http://creativecommons.org/licenses/by/3.0/). 